\title{
A Left-Handed, Stem-Twining Plant from the Miocene Shanwang Formation of Eastern China
}

\author{
Qi Wang ${ }^{1 *}$, Si Shen ${ }^{1}$, Zhenyu Li $^{1^{*}}$ \\ State Key Laboratory of Systematic and Evolutionary Botany, Institute of Botany, Chinese Academy of Sciences, Beijing, China. \\ Email: *happyking@ibcas.ac.cn, *lizy@ibcas.ac.cn
}

Received February 22 ${ }^{\text {nd }}, 2013$; revised April 15 ${ }^{\text {th }}, 2013$; accepted May $1^{\text {st }}, 2013$

Copyright (C) 2013 Qi Wang et al. This is an open access article distributed under the Creative Commons Attribution License, which permits unrestricted use, distribution, and reproduction in any medium, provided the original work is properly cited.

\begin{abstract}
Twining stems of plants are very common in extant tropical and subtropical forests, and the climbing growth habit of plants may be an evolutionary innovation and ecological adaptation to either closed, shady or open, edge environments. However, the origin of handedness in climbing plants remains unclear. Here we report a Miocene (ca. 16 million years ago) macrofossil from the Shanwang Formation of Shandong Province, Eastern China, unequivocally exhibiting the first direct fossil evidence for a left-handed, stem-twining growth habit in plants. This fossil plant bears a thicker, slightly curved supporting stem (2 - $3.5 \mathrm{~mm}$ wide), which is loosely, spirally twined by a thinner stem (1.5 - $2 \mathrm{~mm}$ wide), possibly representing part of distal branches from a liana or vine.
\end{abstract}

Keywords: Climbing Growth Habit; Handedness; Liana; Miocene; Shanwang Formation; Stem-Twining Plants; Vine

\section{Introduction}

Climbing plants (lianas and vines) are abundant and diverse in tropical and subtropical forests [1-7], and some (e.g., pumpkins, cucumbers, grapes, and wisterias) have been widely cultivated by humans (Figure 1). They are mechanically dependent climbers and differ from selfsupporting plants (trees and shrubs) in possessing a wealth of climbing mechanisms such as twining stems, clasping tendrils, modified leaves, hooks and spines, retrorse barbs, and adhesive, adventitious roots [3], by which climbers attach themselves to supporting media and ascend towards higher light exposure levels. Interestingly, the twining stems of living climbers have left-handedness and right-handedness as well as a global tendency towards right-handedness [5]. As displayed on many levels from microscopic elementary particles, atoms, amino acids, proteins, DNA (i.e., Deoxyribose Nucleic Acid), and bacteria to macroscopic galaxies, planets, cyclones, plants, animals, and human beings, the phenomenon of left-handedness and right-handedness has attracted extensive attention [8-12]. However, it has remained enigmatic for the origin and preference of handedness in climbing plants since Darwin's time [5,13,14].

The fossil record of climbing plants provides a historical perspective for their early evolution. So far, plants

${ }^{*}$ Corresponding authors. with tendril-, leaf-, hook- and root-twining mechanisms have been confirmed in Carboniferous-Permian (ca. 359 - 252 million years ago) coal swamp forests of Euramerica, but stem-twining climbers very common in extant tropical and subtropical forest ecosystems previously have not been directly observed in the fossil record [15, 16]. Here we describe a Miocene (ca. 16 million years ago) fossil from diatomaceous shales of the Shanwang Formation at Linqu County, Shandong Province in eastern China, unequivocally exhibiting the first direct macrofossil evidence of twining stems.

\section{Material and Methods}

The fossil presented here was collected from diatomaceous shales of the Shanwang Formation at Shanwang (lat. $36^{\circ} 54^{\prime} \mathrm{N}$, long. $118^{\circ} 20^{\prime} \mathrm{E}$ ), $22 \mathrm{~km}$ east of Linqu County, Shandong Province, eastern China (Figure 2). Shanwang is famous for exquisitely preserved fossil insects, ostracodes, spiders, fish, amphibians, reptiles, birds, mammals, and plants in lacustrine deposits that have been studied since the 1930s [17-20]. This locality has yielded abundant plant macrofossils that have been assigned to 50 families, 104 genera, and 155 species, which are predominated by dicotyledonous angiosperms [21]. The age of this formation is correlated as late Early Miocene-early Middle Miocene (ca. 16 million years ago 


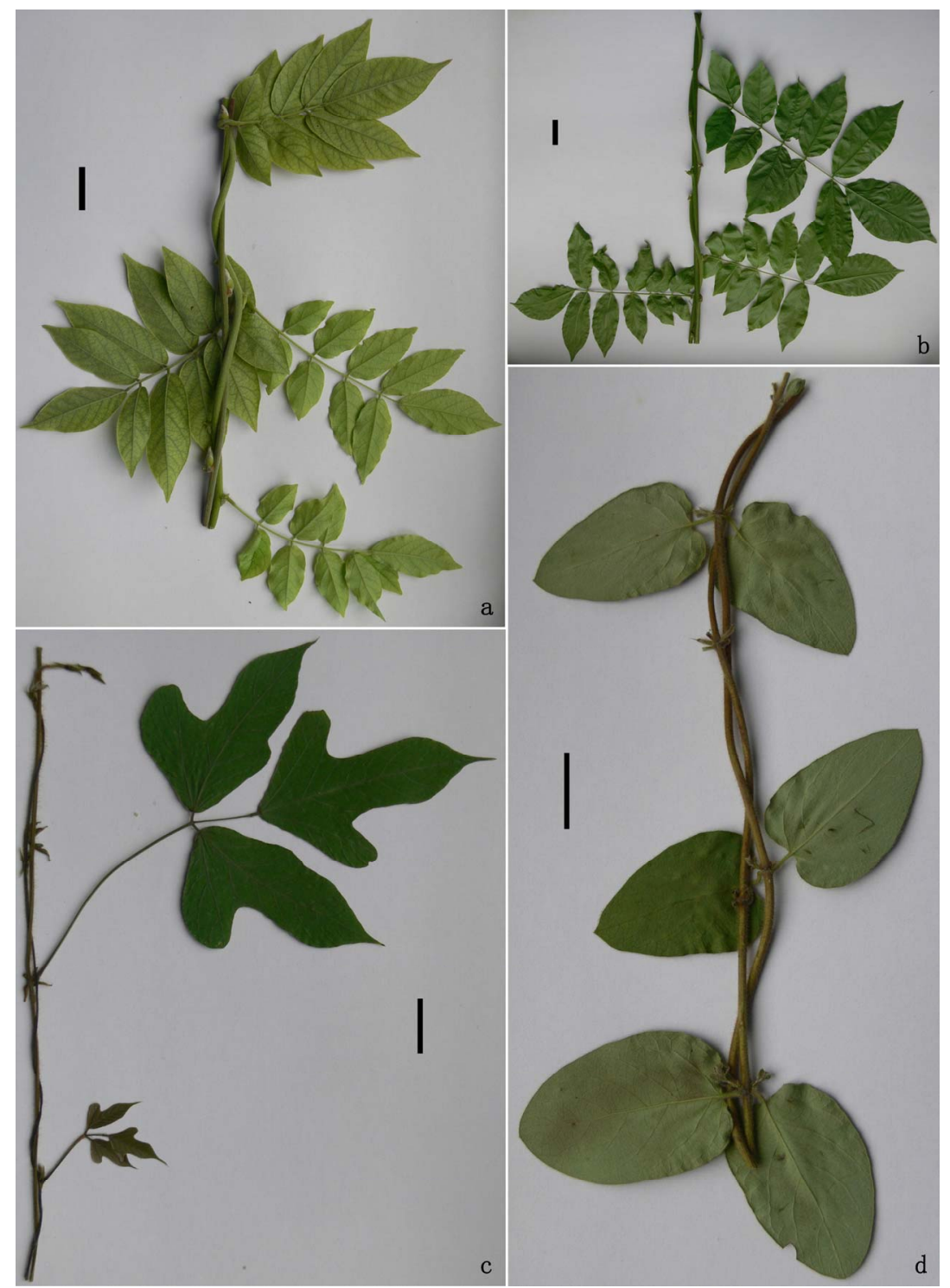

Figure 1. Distal branches of four extant, stem-twining plants cultivated at the Institute of Botany, CAS, Beijing. (a) Wisteria sinensis (Sims) Sweet, showing a right-handed twining and alternate leaves; (b) Wisteria floribunda (Willd.) DC., showing a left-handed twining and alternate leaves; (c) Pueraria montana (Lour.) Merr., showing a right-handed twining and alternate leaves; (d) Lonicera japonica Thunb., showing a left-handed twining and opposite leaves. Bars, $2 \mathrm{~cm}$.

[22]) on the basis of mammalian faunas and radiometric data [23].

This specimen was preserved as branch compressions with a little organic material remaining on a diatomaceous slab (Figure 3(a)), which was prepared with sharp needles to reveal morphological features. An attempt to obtain cuticles was unsuccessful. Photographs were taken with a digital camera (Panasonic DMC-FZ30). The illustration (Figure 3(d)) was drawn using CorelDraw 10.0 program. Distal branches (Figures 1(a)-(d)) of four extant stem-twining plants cultivated at the Institute of Botany, Chinese Academy of Sciences (CAS) were collected to compare with the fossil presented here. The fossil specimen (PE-20120314) was deposited at the Chinese Na- tional Herbarium (PE), Institute of Botany, CAS, Beijing, China.

\section{Results}

Being devoid of cuticles, laterally attached leaves, and other useful characters, the identity of this fossil specimen can not exactly be determined, and open nomenclature is adopted here. Hence, this fossil is classified into "Plantae Incertae sedis" with a description as follows.

The fossil exhibits a clockwise (left-handed) twining direction (Figures 3(a)-(c)). The twining stem is thinner, ca. $128 \mathrm{~mm}$ long and 1.5 - $2 \mathrm{~mm}$ wide, which twines a thicker supporting stem in a loose spiral. The supporting 

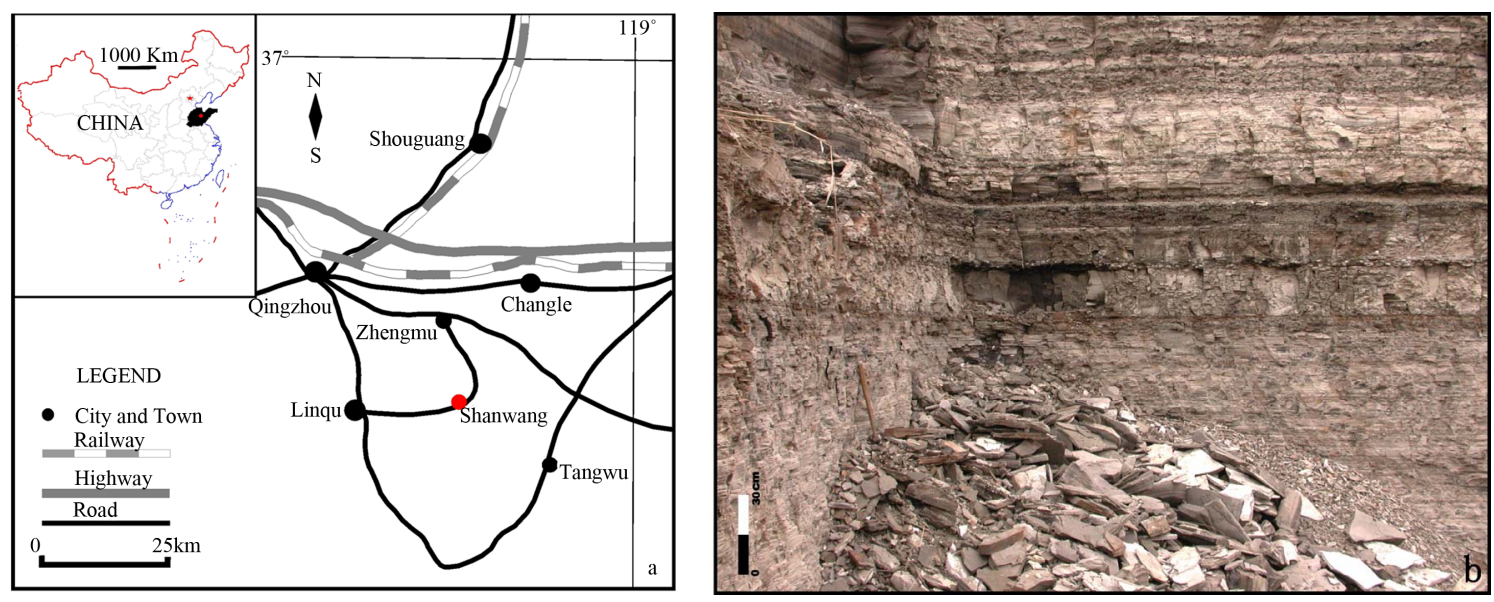

Figure 2. Location and stratigraphy of the Shanwang Formation of Eastern China. (a) Red dot refers to the fossil locality; (b) Showing diatomaceous shales of the Shanwang Formation.
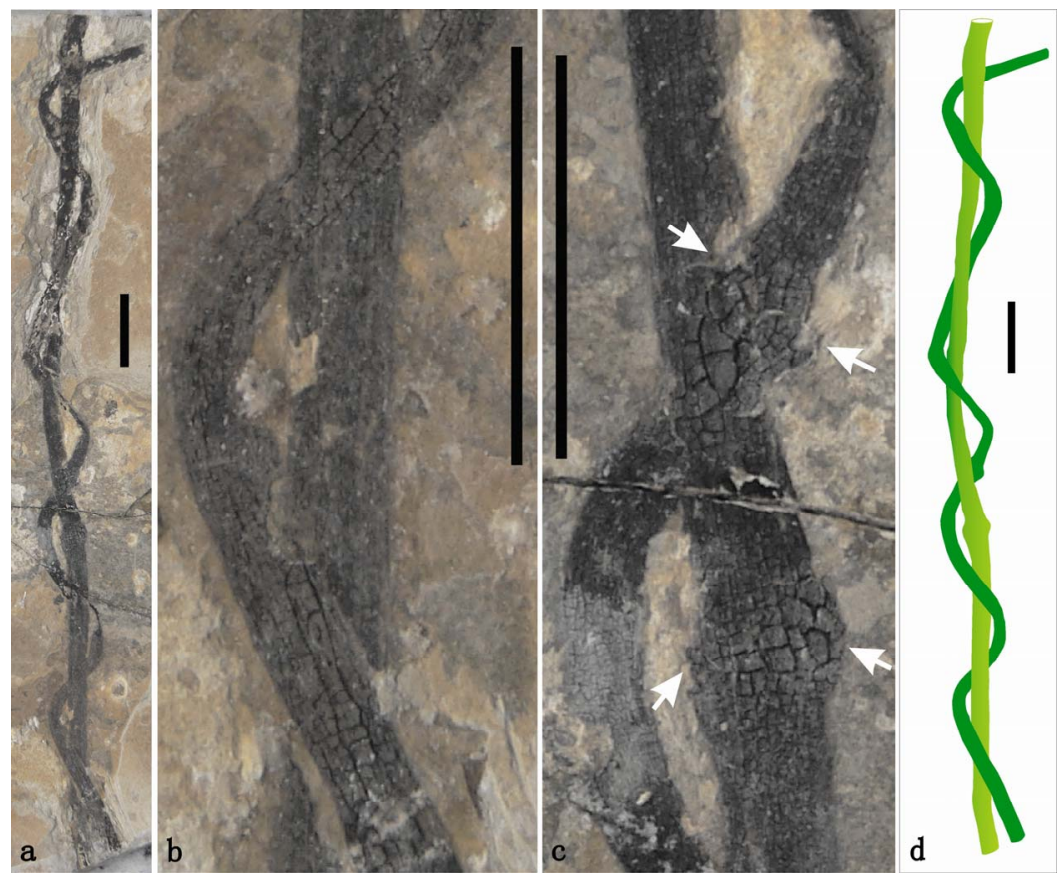

Figure 3. A left-handed, stem-twining fossil from the Miocene Shanwang Formation of Eastern China. (a) Two stems, showing a clockwise (left-handed) twining growth habit. PE-20120314; (b) Enlarged view near the base of stems, showing a lefthanded twining direction; (c) Enlarged view near the middle of stems, showing longitudinal striations, carbonized cracks on the surface, and slightly, bilaterally-bulged node (arrowheads); (d) A schematic reconstruction of this fossil plant. Bars, $1 \mathrm{~cm}$.

stem is slightly curved, ca. $115 \mathrm{~mm}$ long and 2 - $3.5 \mathrm{~mm}$ wide. Both stems appear to have long internodes and a slightly, bilaterally-bulged node (Figure 3(c)), implying that there may have borne opposite appendages (e.g., leaves) in life. There are similar, longitudinal striations on the surface of two stems. Cuticles are unavailable. The texture appears to be woody.

In light of the loose spirals and bilaterally bulged nodes, the twining stem presented here is not a tendril around the supporting stem. Both the supporting stem and twining stem have similar longitudinal striations on the sur- face and slightly bulged nodes possibly with opposite appendages, so this fossil is far more likely to be detached from the same parent plant, representing a part of distal branches from a liana or vine. A schematic reconstruction of this fossil plant is given here (Figure 3(d)).

Prior to this study, the existence of stem-twining plants at Shanwang has been inferred by leaf or/and fruit fossils that were classified into living vine or liana genera such as Wisteria Nutt., Pueraria DC., and Lonicera L. [17, 19-21,24,25]. In this study, we provide the first direct macrofossil evidence for a stem-twining habit in plants. 


\section{Discussion}

The climbing growth habit of plants may be an evolutionary innovation and ecological adaptation to either closed, shady or open, edge environments $[2-4,7,15,16]$. As land plants began to form the earliest forests in the Middle Devonian (ca. 393 - 383 million years ago) [26], climbing habits might have occurred, for example $L e$ clercqia uncinata Xu et al., a herbaceous lycopsid with hooked leaves [27]. Today twining stems of climbing plants are very common in tropical and subtropical forests, but prior to this study little is known about their direct macrofossils through time, even in the Mesozoic and Cenozoic. To a large extent, much fewer quantities available for fossilization of twigs and stems than other detached organs (pollen, flowers, seeds, and leaves) [28] may have resulted in an extremely low probability for the twining stems preserved in rocks. As evidenced here from the subtropical Shanwang flora, therefore, the diversity of climbing plants may have been underestimated in subtropical and tropical evergreen forests during the Mesozoic and Cenozoic.

\section{Acknowledgements}

The authors thank Prof. D. L. Dilcher, Indiana University and Dr. C. J. Cleal, National Museum Wales for their helpful suggestions. Mr. Y. G. Tang, Linyi City for collecting the specimen. Financial support was provided by grants of the National Natural Science Foundation of China (Nos. 40830209 and 40972015), the State Key Laboratory of Systematic and Evolutionary Botany, CAS (No. 56176G1044), and the State Key Laboratory of Palaeobiology and Stratigraphy, Nanjing Institute of Geology and Palaeontology, CAS (no. 123106) to Q. W. and Z. Y. Li.

\section{REFERENCES}

[1] E. A. Menninger, "Flowering Vines of the World,” Hearthside Press, New York, 1970.

[2] F. E. Putz and H. A. Mooney, "The Biology of Vines," Cambridge University Press, Cambridge, 1991.

[3] S. A. Schnitzer and F. Bongers, "The Ecology of Lianas and Their Role in Forests,” Trends in Ecology \& Evolution, Vol. 17, No. 5, 2002, pp. 223-230. doi:10.1016/S0169-5347(02)02491-6

[4] R. A. Londré and S. A. Schnitzer, "The Distribution of Lianas and Their Change in Abundance in Temperate Forests over the Past 45 Years,” Ecology, Vol. 87, No. 12, 2006, pp. 2973-2978. doi:10.1890/0012-9658(2006)87[2973:TDOLAT]2.0.CO; $\underline{2}$

[5] W. Edwards, A. T. Moles and P. Franks, "The Global Trend in Plant Twining Direction," Global Ecology and Biogeography, Vol. 16, No. 6, 2007, pp. 795-800.

\section{doi:10.1111/j.1466-8238.2007.00326.x}

[6] F. Carrasco-Urra and E. Gianoli, "Abundance of Climbing Plants in a Southern Temperate Rain Forest: Host Tree Characteristics or Light Availability?” Journal of Vegetation Science, Vol. 20, No. 6, 2009, pp. 1159-1162. doi:10.1111/j.1654-1103.2009.01115.x

[7] R. J. Burnham and C. Revilla-Minaya, "Phylogenetic Influence on Twining Chirality in Lianas from Amazonian Peru,” Annals of the Missouri Botanical Garden, Vol. 98, No. 2, 2011, pp. 196-205. doi:10.3417/2008080

[8] R. A. Hegstrom and D. K. Kondepudi, "The Handedness of the Universe,” Scientific American, Vol. 262, No. 1, 1990, pp. 108-115. doi:10.1038/scientificamerican0190-108

[9] J. D. Watson and F. H. C. Crick, "A Structure for Deoxyribose Nucleic Acid,” Nature, Vol. 171, No. 4356, 1953, pp. 737-738. doi:10.1038/171737a0

[10] M. Novotny and G. J. Kleywegt, "A Survey of LeftHanded Helices in Protein Structures," Journal of Molecular Biology, Vol. 347, No. 2, 2005, pp. 231-241. doi:10.1016/j.jmb.2005.01.037

[11] T. Hashimoto, "Molecular Genetic Analysis of Left-Right Handedness in Plants," Philosophical Transactions of the Royal Society B, Vol. 357, No. 1422, 2002, pp. 799-808. doi:10.1098/rstb.2002.1088

[12] H. J. Liu, "History of Nature and Beauty of Nature: A Case Study of Plant's Stem,” In: Y. Z. Li, Ed., Art and Science, Tsinghua University Press, Beijing, 2005, pp. 67-76.

[13] C. Darwin, "On the Movements and Habits of Climbing Plants,” Journal of the Linnean Society (Botany), Vol. 9, 1867, pp. 1-118.

[14] G. H. Li, H. X. Ci, Y. A. Liu and J. P. Su, "Phylogenetic Analysis of Chirality of Twining Plants," Agricultural Science \& Technology, Vol. 11, No. 2, 2010, pp. 34-38.

[15] M. Krings, H. Kerp, T. N. Taylor and E. L. Taylor, "How Paleozoic Vines and Lianas Got off the Ground: On Scrambling and Climbing Carboniferous-Early Permian Pteridosperms,” Botanical Review, Vol. 69, No. 2, 2003, pp. 204-224. doi:10.1663/0006-8101(2003)069[0204:HPVALG]2.0.C $\underline{\mathrm{O} ; 2}$

[16] R. J. Burnham, "An Overview of the Fossil Record of Climbers: Bejucos, Sogas, Trepadoras, Lianans, Cipós, and Vines," Revista Brasileira Paleontologia, Vol. 12, No. 2, 2009, pp. 149-160. doi:10.4072/rbp.2009.2.05

[17] H. H. Hu and R. W. Chaney, "A Miocene Flora from Shantung Province, China, Part 1. Introduction and Systematic Considerations," Carnegie Institution of Washington Publication, Vol. 507, 1938, pp. 1-82.

[18] H. Yang and S. P. Yang, "The Shanwang Fossil Biota in Eastern China: A Miocene Konservät-lagerstätte in Lacustrine Deposits,” Lethaia, Vol. 27, No. 4, 1994, pp. 345-354. doi:10.1111/j.1502-3931.1994.tb01585.x

[19] Q. Wang, "Fruits of Hemitrapa (Trapaceae) from the Miocene of Eastern China, Their Correlation with Sporotrapoidites erdtmanii Pollen and Paleobiogeographic Implications,” Journal of Paleontology, Vol. 86, No. 1, 2012, 
pp. 156-166. doi:10.1666/11-061.1

[20] Q. Wang, S. R. Manchester, H.-J. Gregor, S. Shen and Z. Y. Li, "Fruits of Koelreuteria (Sapindaceae) from the Cenozoic throughout the Northern Hemisphere: Their Ecological, Evolutionary and Biogeographic Implications,” American Journal of Botany, Vol. 100, No. 2, 2013, pp. 422-449. doi:10.3732/ajb.1200415

[21] B. Sun, "Shanwang Plant Fossils," Shandong Science and Technology Publishing House, Ji’nan, 1999.

[22] F. M. Gradstein, J. G. Ogg, M. D. Schmitz and G. M. Ogg, “The Geologic Time Scale 2012,” Elsevier, Boston, 2012.

[23] T. Deng, “Chinese Neogene Mammal Biochronology," Vertebrata PalAsiatica, Vol. 44, No. 2, 2006, pp. 143163.

[24] Q. Wang, D. L. Dilcher, X. Y. Zhu, Y. L. Zhou and T. A. Lott, "Fruits and Leaflets of Wisteria (Leguminosae, Papilionoideae) from the Miocene of Shandong Province, Eastern China,” International Journal of Plant Sciences,
Vol. 167, No. 5, 2006, pp. 1061-1074. doi:10.1086/502717

[25] Q. Wang, S. R. Manchester and D. L. Dilcher, "Fruits and Foliage of Pueraria (Leguminosae, Papilionoideae) from the Neogene of Eurasia, and Their Biogeographic Implications," American Journal of Botany, Vol. 97, No. 12, 2010, pp. 1982-1998. doi:10.3732/ajb.1000167

[26] W. E. Stein, C. M. Berry, L. V. Hernick and F. Mannolini, "Surprisingly Complex Community Discovered in the Mid-Devonian Fossil Forest at Gilboa,” Nature, Vol. 483, No. 7387, 2012, pp. 78-81. doi:10.1038/nature10819

[27] H. H. Xu, C. M. Berry, Y. Wang and J. E. A. Marshall, "A New Species of Leclercqia Banks, Bonamo et Grierson (Lycopsida) from the Middle Devonian of North Xinjiang, China, with A Possible Climbing Habit,” International Journal of Plant Sciences, Vol. 172, No. 6, 2011, pp. 836-846. doi:10.1086/660195

[28] N. F. Hughes, "Palaeobiology of Angiosperm Origins," Cambridge University Press, Cambridge, 1976. 